\title{
Kinetic modeling of simultaneous saccharification and fermentation of corn starch for ethanol production*
}

\author{
Wojciech Białas ${ }^{\bowtie}$, Adrian Czerniak and Daria Szymanowska-Powałowska \\ Department of Biotechnology and Food Microbiology, Poznan University of Life Sciences, Poznań, Poland
}

Fuel ethanol production, using a simultaneous saccharification and fermentation process (SSF) of native starch from corn flour, has been performed using Saccharomyces cerevisiae and a granular starch hydrolyzing enzyme. The quantitative effects of mash concentration, enzyme dose and $\mathrm{pH}$ were investigated with the use of a BoxWilson central composite design protocol. Proceeding from results obtained in optimal fermentation conditions, a kinetics model relating the utilization rates of starch and glucose as well as the production rates of ethanol and biomass was tested. Moreover, scanning electron microscopy (SEM) was applied to investigate corn starch granule surface after the SFF process. A maximum ethanol concentration of $110.36 \mathrm{~g} / \mathrm{l}$ was obtained for native corn starch using a mash concentration of $25 \%$, which resulted in ethanol yield of $85.71 \%$. The optimal conditions for the above yield were found with an enzyme dose of $2.05 \mathrm{ml} / \mathrm{kg}$ and $\mathrm{pH}$ of 5.0 . These results indicate that by using a central composite design, it is possible to determine optimal values of the fermentation parameters for maximum ethanol production. The investigated kinetics model can be used to describe SSF process conducted with granular starch hydrolyzing enzymes. The SEM micrographs reveal randomly distributed holes on the surface of granules.

Key words: native starch; optimization, modeling, kinetics, simultaneous saccharification and fermentation

Received: 30 October, 2013; revised: 25 February, 2014; accepted: 27 February, 2014; available on-line: 20 March, 2014

\section{INTRODUCTION}

Ethanol, a chemical alternative to petroleum-derived fuel, is produced from fermentation of carbohydrates such as starches, which are present in plants. Ethanol provides a renewable energy source that produces a number of additional benefits, including limited greenhouse gas emissions and creation of new employment opportunities by enhancing economic benefits in rural areas (Wyman, 2003).

It is well known that fermentation of starch is more complex than fermentation of sugars such as glucose or sucrose, because starch must first be converted into fermentable sugars and then into ethanol. To reach an almost total degradation of starch, two main groups of amylolytical enzymes are required: one comprised of liquefying thermostable $\alpha$-amylases, and the other of saccharifying glucoamylases (Senn \& Pieper, 2001). In conventional ethanol technology, a starchy feedstock such as corn flour, is first slurried with water containing a heat- stable $\alpha$-amylase. The preliminary addition of $\alpha$-amylase is required in order to decrease the viscosity of the mash and to facilitate the cooking operation. This slurry is then cooked at high temperatures $\left(90-95^{\circ} \mathrm{C}\right)$ to gelatinize and liquefy the starch. During the mashing process, starch polymer is hydrolyzed by $\alpha$-amylase to produce shorter chains, namely dextrins, maltose and maltotriose. The resulting mash is then cooled to $60^{\circ} \mathrm{C}$ and a glucoamylase is added which converts dextrins to fermentable sugars, these being mainly glucose and maltose (Power, 2003). In the final step of the process, yeast are added and incubated at temperatures below $35^{\circ} \mathrm{C}$ for $48-72 \mathrm{~h}$ to ferment the sugars to ethanol. Due to the high energy consumption during the mashing process, the current production cost of traditional starch substrate processing for ethanol are high. According to Lim et al. (2003) the energy demand of the conventional cooking process is equivalent to $30-40 \%$ of the fuel value of ethanol produced. Hence to compete with the existing fossil fuel industry and become commercially viable, the cost must be reduced.

There are several possible ways to approach this problem. The most straightforward is to design new amylases capable of raw starch digestion (GSHE - the granular starch hydrolyzing enzymes). It is well known that amylases from cereals are capable of hydrolyzing raw starch, which is essential in the breakdown of stored carbohydrates. In addition to green plant sources, enzymes reported to have the ability to digest raw starch were also found in microbial sources. Recently, seven highly active enzyme systems with raw starch hydrolytic capabilities were created by using biological combinatorial processes, using naturally occurring amylases. According to Robertson et al. (2006) these systems have the potential to overcome limitations of a natural set of enzymes utilized currently. Application of tailored GSH enzymes eliminates the cost-intensive liquefaction cooking step, and thus reduces the energy input per unit of ethanol produced. In addition to the advantages already mentioned, another attractive feature of this enzymatic complex is that it can be used to break down starch molecules in very concentrated mashes, in which the dry solid content

e-mail: wbialas@up.poznan.pl

*Presented at the 3-rd Workshop on Microbiology "MIKROBIOT 2013" in Łódź, Poland.

Abbreviations: St starch concentration $\left(\mathrm{kg} / \mathrm{m}^{3}\right)$; $\mathrm{Glu}$, glucose concentration $\left(\mathrm{kg} / \mathrm{m}^{3}\right) ; \mathrm{X}$, biomass concentration $\left(\mathrm{kg} / \mathrm{m}^{3}\right)$; Et, ethanol concentration $\left(\mathrm{kg} / \mathrm{m}^{3}\right)$; Enz, enzyme concentration $\left(\mathrm{U} / \mathrm{m}^{3}\right) ; \mathrm{k}_{\mathrm{st}}$, rate constant $(\mathrm{kg} / \mathrm{U} \cdot \mathrm{h}) ; \mathrm{K}$, inhibition and saturation constants $\left(\mathrm{kg} / \mathrm{m}^{3}\right)$; $\mathrm{Km}$, Michaelis' constant $\left(\mathrm{kg} / \mathrm{m}^{3}\right) ; \mathrm{Qp}$, specific ethanol production rate $(1 / \mathrm{h}) ; \mathrm{R}$, starch utilization rate $\left(\mathrm{kg} / \mathrm{m}^{3} / \mathrm{h}\right) ; \mathrm{R}_{\mathrm{Glu}}$ formation, glucose formation rate $\left(\mathrm{kg} / \mathrm{m}^{3} / \mathrm{h}\right) ; R_{\text {Glu }}$ utilization, glucose utilization rate $\left(\mathrm{kg} / \mathrm{m}^{3} / \mathrm{h}\right) ; \mathrm{Yp} / \mathrm{s}$, yield coefficient of product $(\mathrm{kg} / \mathrm{kg}) ; \mathrm{Yx} / \mathrm{s}$, yield coefficient of cell growth $(\mathrm{kg} / \mathrm{kg}) ; \mathrm{T}$, time $(\mathrm{h}) ; \mu$, specific growth rate (1/h). Subscripts: 0 , initial; max, maximum 
oscillates in the range of $12-38 \%$ wt. Possible drawbacks of this technology include the cost and the amount of enzyme required for the process, and the increased chance of microbial contamination and corresponding loss of yield because partial pasteurization of the mash during the heating process does not occur. The heat applied during standard ethanol process also helps to release the starch that is bound to a fiber or proteins, and inactivates some toxins that may be present in the grain (Nichols et al., 2006).

Great attention is being paid to optimization of the fermentation processes. It is well known that when starch is used as a raw material, amylases are strongly inhibited by hydrolysis products, such as glucose. This inconvenience can be overcome by a simultaneous saccharification and fermentation process (SSF), which combines enzymatic hydrolysis with fermentation. Furthermore, the SSF process also reduces osmotic stress since the yeast cells are exposed to a relatively lower sugar concentration, thereby offering a possibility of higher production rates. An additional advantage of SSF is that a multistage process for the conversion of starch into ethanol is carried out in one bioreactor, which provides not only a reduction in the overall fermentation time but also a reduction in the investment and operational costs (Kobayashi et al., 1998). However, in spite of these advantages, there are some drawbacks of using SSF, such as different optimal temperatures for the action of $\alpha$ and glucoamylase and the growth of yeast, which means that conditions used in SSF cannot be optimal for both, the enzymes and the yeast (Öhgren et al., 2007). Thus, the SSF temperature, which is usually around $35^{\circ} \mathrm{C}$, is a compromise between optimal temperatures for hydrolysis and fermentation. According to Philippidis \& Smith (1995), hydrolysis is the main rate-limiting process in SSF, hence in recent years thermotolerant yeast and bacteria have been used to raise the process temperature close to the optimal hydrolysis temperature. Ward et al. (1995) found that a thermotolerant yeast Kluveromyces marxianus in a mixed culture with thermophilic filamentous fungi Taloromyces emersonii, produced ethanol with a high yield at $45^{\circ} \mathrm{C}$, using a starch-containing media as a substrate.

Since 1970 the SSF process has been used and mentioned in general reports (Verma et al, 2000; Öhgren et al., 2006) but little has been cited on the SSF optimization of raw corn flour with a combination of GSHE amyloglucosidase and yeast Saccharomyces cerevisiae. Therefore the present work was carried out to identify optimal process conditions for the simultaneous saccharification and fermentation of granular corn starch using GSHE amyloglucosidase and Saccharomyces cerevisieae Ethanol Red yeast through a response surface methodology. Additionally, an unstructured kinetic model describing the rate of change in the starch, glucose and ethanol, as well as the biomass concentration, has also been tested.

\section{MATERIALS AND METHODS}

Raw material. Commercially available corn flour (BIO CORN, Ziebice, Poland) was used as a raw material for fermentation. It had a median diameter of 250 $\mu \mathrm{m}$, and contained $12.8 \%$ water, $90.05 \%$ starch, and $0.1 \%$ ash.

Yeast. A freeze dried distiller's yeast, Ethanol Red (Saccharomyces cerevisiae), obtained from Lesaffre Company (Marcq en Baroeul, France) was used in this study for production of ethanol from the corn mashes. The num- ber of living cells at packing was above $2.0 \times 10^{10} / \mathrm{g}$, as defined by the manufacturer.

Enzymes. A mixture of granular starch hydrolyzing enzymes, containing Aspergillus kawachi $\alpha$-amylase expressed in Trichoderma reesei, and a glucoamylase from Aspergillus niger were employed in this study (STARGEN 001, Genencore International, USA). The enzymatic activity of this set of enzymes was $\geq 456$ GSHU/g (Granular Starch Hydrolyzing Units), as defined by Genencore International. In addition, fungal acid protease GC 106 (Aspergillus niger), also obtained from Genencore International, was added to the mashes. The enzymatic activity of GC 106 was $\geq 1000$ SAPU/g (Spectrophotometric Acid Protease Units), as defined by the manufacturer.

Other chemicals. All other chemicals used in this study, purchased from various commercial suppliers, were of analytical grade purity.

Experimental design and statistics. The SSF optimization, by the classical method of a single-dimensional search involving changing of one variable while fixing the others at a certain level, is laborious and timeconsuming, especially when the number of variables is large. Furthermore, the other significant disadvantage of the one-factor-at-a-time strategy is that it fails to consider any possible interactions between factors. In fact, if interactions are present and the factorial experimental strategy is not used, incorrect or misleading results may be obtained (Montgomery, 2001). An alternative and more efficient approach to the investigation of a fermentation systems is the use of statistical methods. Many statistical experimental design methods are currently being employed in bioprocess optimization. Among these, response surface methodology (RSM), which employs a combination of mathematical and statistical techniques, is the one most suitable for identifying the effect of individual independent variables and their interactions, and for seeking optimal conditions for a multivariable system efficiently (Montgomery \& Runger, 2003). A three-factor $(\mathrm{k}=3)$, five-level central composite design (CCD) was used in this study. The effects of corn flour concentration in the mash $\left(\mathrm{X}_{1}\right)$, the dose of GSHE $\left(\mathrm{X}_{2}\right)$ and the mash $\mathrm{pH}\left(\mathrm{X}_{3}\right)$, were selected as process (independent) variables. Ethanol concentration $\left(Y_{1}, g / l\right)$, and the overall process yield $\left(\mathrm{Y}_{2}, \%\right.$ of theoretical ethanol yield) were the responses (dependent variables). As shown in Table 1 the variable levels $\mathrm{X}_{\mathrm{i}}$ were coded as $\mathrm{x}_{\mathrm{i}}$ according to the following equation (1):

$$
x_{i}=\frac{2 X_{i}-X_{(\min ) i}-X_{(\max ) i}}{X_{(\max ) i}-X_{(\min ) i}}
$$

where $x_{i}$ is the dimensionless value of an independent variable, $\mathrm{X}_{\mathrm{i}}$ the real value of an independent variable and $\mathrm{X}_{(\min )}, \mathrm{X}_{(\max ) \mathrm{i}}$ are the lower and the upper limit of the independent variable, respectively. The set points were selected according to the results obtained during a preliminary study. This design was chosen for its ability to estimate second-order effects, to detect the interrelationship between the factors, and to identify the response optima according to the experimenter formulated criteria. This experimental plan was divided into three blocks, comprised of 20 actual experiments and including 6 replicates. Replication allowed determination of experimental error and increased precision of the estimates. The order in which experiments were performed was randomised, according to the requirement for observations to be distributed independently and randomly which, in addition, helps to avoid the influence of unknown nuisance vari- 
Table 1. Factor variation intervals

\begin{tabular}{lccccc}
\hline \multirow{2}{*}{ Factors } & \multicolumn{5}{c}{ Variation levels } \\
\cline { 2 - 6 } & -1.4 & -1.0 & 0 & +1.0 & +1.4 \\
\hline $\mathrm{X}_{1}$ - mash concentration [\% wt.] & 23.0 & 25.0 & 30.0 & 35.0 & 37.0 \\
\hline $\mathrm{X}_{2}$ - dose of GSHE [ml/kg flour dry matter] & 0.30 & 0.75 & 1.875 & 3.00 & 3.45 \\
\hline $\mathrm{X}_{3}-$ mash $\mathrm{pH}$ & 3.20 & 3.50 & 4.25 & 5.00 & 5.30 \\
\hline
\end{tabular}

Simultaneous saccharification and fermentation. The SSF experiments were performed in 250 $\mathrm{ml}$ Erlenmeyer flasks, each containing $200 \mathrm{ml}$ of fermentation medium formulated according to the experimental design (Table 1). A weighed amount of corn flour was suspended in sterilized water. The $\mathrm{pH}$ of the fermentation broth was measured at each sampling and ables. The design matrix of the central composite design (CCD) for $\mathrm{k}=3$ is shown in Table 2 .

A multiple regression analysis of the data was carried out in order to obtain empirical models that define the response $\left(Y_{i}\right)$ in terms of the independent variables:

$$
\begin{aligned}
& \mathrm{Y}_{\mathrm{i}}=\mathrm{b}_{0}+\mathrm{b}_{1} \cdot \mathrm{x}_{1}+\ldots+\mathrm{b}_{\mathrm{k}} \cdot \mathrm{x}_{\mathrm{k}}+\mathrm{b}_{12} \cdot \mathrm{x}_{1} \cdot \mathrm{x}_{2}+\ldots \\
& +b_{k-1 \cdot k} \cdot x_{k-1} \cdot x_{k}+b_{11} \cdot x_{1}{ }^{2}+\ldots+b_{k k} \cdot x_{k}{ }^{2}
\end{aligned}
$$

Coefficients of the polynomial, represented by $b_{0}$ (constant term), $b_{k}$ (linear effects), $b_{k k}$ (quadratic effects), and $b_{k-1 \cdot k}$ (interaction effects) were correlated to the responses $\left(Y_{\mathrm{j}}\right)$. Statistical analysis was carried out in coded data sets in order to simplify interpretation of the results. The accuracy and general ability of the above polynomial model was evaluated by an adjusted coefficient of determination Adj- $\mathrm{R}^{2}$, the significance of total regress F-value and the non-significance of lack of fit F-value. The commercial software STATISTICA, version 6.0 PL from StatSoft, Inc., was used for regression and graphical analyses of the data obtained. adjusted by addition of either $10 \%$ wt. $\mathrm{H}_{2} \mathrm{SO}_{4}$ or $20 \%$ wt. $\mathrm{NaOH}$. In all cases, the medium was supplemented with acid protease GC $106(40 \mu \mathrm{l} / \mathrm{kg}$ corn flour dry matter) and chloramphenicol $(50 \mu \mathrm{g} / \mathrm{L}$ of the fermentation medium). Fermentation was initiated with addition of freeze-dried distiller's yeast Ethanol Red $(0.5 \mathrm{~g} / \mathrm{L}$ of fermentation medium). The number of living cells in the were incubated in a rotary shaker $(200 \mathrm{rpm})$ at $35^{\circ} \mathrm{C}$ for $72 \mathrm{~h}$. Samples were taken and analyzed for yeast cell viability as well as for the starch, glucose and ethanol concentration after fermentation. Average results of triplicate experiments are shown.

Model validation. In order to validate the regression model, a new series of fermentation trials was carried out in triplicate. Using the point prediction capability of the software, values of dependent variables were predicted, together with the $95 \%$ confidence intervals, and then compared with the experimental results.

Kinetics studies. The SSF kinetics of mashes containing native corn starch were described in a modified unstructured kinetic model developed by Kroumov et al. (2006). Kinetics experiments were carried out in a $5 \mathrm{~L}$ medium was $1.0 \times 10^{7}$ cells $/ \mathrm{ml}$ after inoculation. Flasks

Table 2. Central composite design: $2^{3}+(2 \times 3)+6=20 . X_{1}-$ corn flour concentration (\% wt.), $X_{2}-$ GSHE dose (ml/kg of dry matter),

\begin{tabular}{|c|c|c|c|c|c|c|c|}
\hline \multirow{2}{*}{ Run } & \multirow{2}{*}{ Block } & \multicolumn{5}{|c|}{ Actual values $X_{i}$} & \multirow{2}{*}{$\frac{\text { Coded values } \mathrm{x}_{\mathrm{i}}}{\mathrm{x}_{3}}$} \\
\hline & & $\mathrm{X}_{1}$ & $\mathrm{X}_{2}$ & $X_{3}$ & $\mathrm{x}_{1}$ & $\mathrm{x}_{2}$ & \\
\hline 1 & 1 & 25.00 & 3.000 & 5.00 & -1.0 & 1.0 & 1.0 \\
\hline 2 & 1 & 30.00 & 1.875 & 4.25 & 0.0 & 0.0 & 0.0 \\
\hline 3 & 1 & 35.00 & 3.000 & 3.50 & 1.0 & 1.0 & -1.0 \\
\hline 4 & 1 & 30.00 & 1.875 & 4.25 & 0.0 & 0.0 & 0.0 \\
\hline 5 & 1 & 25.00 & 0.750 & 3.50 & -1.0 & -1.0 & -1.0 \\
\hline 6 & 1 & 35.00 & 0.750 & 5.00 & 1.0 & -1.0 & 1.0 \\
\hline 7 & 2 & 35.00 & 3.000 & 5.00 & 1.0 & 1.0 & 1.0 \\
\hline 8 & 2 & 35.00 & 0.750 & 3.50 & 1.0 & -1.0 & -1.0 \\
\hline 9 & 2 & 25.00 & 3.000 & 3.50 & -1.0 & 1.0 & -1.0 \\
\hline 10 & 2 & 25.00 & 0.750 & 5.00 & -1.0 & -1.0 & 1.0 \\
\hline 11 & 2 & 30.00 & 1.875 & 4.25 & 0.0 & 0.0 & 0.0 \\
\hline 12 & 2 & 30.00 & 1.875 & 4.25 & 0.0 & 0.0 & 0.0 \\
\hline 13 & 3 & 30.00 & 0.300 & 4.25 & 0.0 & -1.4 & 0.0 \\
\hline 14 & 3 & 37.00 & 1.875 & 4.25 & 1.4 & 0.0 & 0.0 \\
\hline 15 & 3 & 30.00 & 1.875 & 4.25 & 0.0 & 0.0 & 0.0 \\
\hline 16 & 3 & 23.00 & 1.875 & 4.25 & -1.4 & 0.0 & 0.0 \\
\hline 17 & 3 & 30.00 & 1.875 & 4.25 & 0.0 & 0.0 & 0.0 \\
\hline 18 & 3 & 30.00 & 1.875 & 3.20 & 0.0 & 0.0 & -1.4 \\
\hline 19 & 3 & 30.00 & 1.875 & 5.30 & 0.0 & 0.0 & 1.4 \\
\hline 20 & 3 & 30.00 & 3.450 & 4.25 & 0.0 & 1.4 & 0.0 \\
\hline
\end{tabular}
$\mathrm{X}_{3}-$ mash $\mathrm{pH}$ 
Table 3. Results of central composite design: $2^{3}+(2 \times 3)+6=20$

\begin{tabular}{|c|c|c|c|c|}
\hline \multirow{2}{*}{ Run } & \multicolumn{2}{|c|}{$\begin{array}{l}\text { Ethanol } \\
\left(Y_{1}\right)[g / l]\end{array}$} & \multicolumn{2}{|c|}{$\begin{array}{l}\text { Overall process yield } \\
\left(\mathrm{Y}_{2}\right)[\%]\end{array}$} \\
\hline & Actual & Predicted & Actual & Predicted \\
\hline 1 & 112.43 & 108.25 & 62.426 & 59.263 \\
\hline 2 & 113.30 & 116.20 & 73.394 & 74.708 \\
\hline 3 & 116.78 & 117.85 & 64.841 & 65.667 \\
\hline 4 & 117.19 & 116.20 & 75.908 & 74.708 \\
\hline 5 & 94.58 & 96.49 & 73.519 & 76.184 \\
\hline 6 & 106.82 & 106.10 & 83.031 & 82.589 \\
\hline 7 & 119.43 & 121.20 & 77.364 & 78.187 \\
\hline 8 & 115.81 & 113.25 & 64.299 & 62.742 \\
\hline 9 & 118.47 & 121.20 & 76.744 & 78.187 \\
\hline 10 & 120.02 & 122.85 & 66.636 & 69.147 \\
\hline 11 & 107.55 & 101.49 & 83.602 & 79.664 \\
\hline 12 & 109.80 & 111.10 & 85.351 & 86.068 \\
\hline 13 & 79.09 & 86.22 & 51.233 & 55.273 \\
\hline 14 & 103.53 & 99.67 & 67.065 & 64.240 \\
\hline 15 & 102.86 & 102.40 & 86.910 & 87.381 \\
\hline 16 & 115.39 & 110.63 & 74.745 & 71.345 \\
\hline 17 & 112.77 & 110.63 & 73.046 & 71.345 \\
\hline 18 & 119.85 & 118.86 & 62.946 & 63.691 \\
\hline 19 & 106.47 & 110.63 & 68.967 & 71.345 \\
\hline 20 & 109.69 & 110.63 & 71.052 & 71.345 \\
\hline
\end{tabular}

batch bioreactor (BIOFLO III, New Brunswick Scientific, New Brunswick, NJ) with 3.0 L working volume, at $35^{\circ} \mathrm{C}, 100 \mathrm{rpm}$ and an initial biomass concentration of $1.0 \times 10^{7}$ cells $/ \mathrm{ml}$. All computations were performed using the Matlab and Simulink Release 2013 (The MathWorks, Inc., Natick, Massachusetts, United States).

Analysis. Samples for the analysis of glucose and ethanol concentrations were first centrifuged at $4000 \times$ $\mathrm{g}$ for $10 \mathrm{~min}$ at $4^{\circ} \mathrm{C}$ (Multifuge 3SR, Germany), filtered through a $0.22 \mu \mathrm{m}$ membrane filter (Millex-GS, Millipore, USA), and then analyzed with an HPLC system (Merck Hitachi, Germany). Glucose and ethanol were separated on Aminex HPX-87P (Bio-Rad, USA) at $30^{\circ} \mathrm{C}$ using $5 \mathrm{mM} \mathrm{H}_{2} \mathrm{SO}_{4}$ solution as the mobile phase at a flow rate of $0.6 \mathrm{ml} / \mathrm{min}$, and then detected with a refractive index detector (Model L-7490, Merck Hitachi, Germany). Starch content was analyzed according to the enzymatic method developed by Holm et al. (1986). Yeast cell populations were determined by a direct microscopic count in a counting chamber after staining with methylene blue. Yeast cell number was recalculated to express the biomass concentration as $\mathrm{kg} / \mathrm{m}^{3}$, according to the data presented by Haddad \& Lindegren (1953).

Isolation and scanning electron microscopy of starch granules from fermented mash. A sample (5 g) of the fermented mash was first centrifuged at $4000 \times \mathrm{g}$ for $10 \mathrm{~min}$ at $25^{\circ} \mathrm{C}$ (Multifuge 3SR, Germany) and then suspended with $45 \mathrm{ml}$ of sterilized water and shaken for 5 minutes. Then, the sample was centrifuged, and the supernatant was discarded. The sediment was mixed with $50 \mathrm{ml}$ of $0.02 \mathrm{M}$ sodium hydroxide and stirred for 15 min at room temperature. The mixture was centrifuged at $4000 \times g$ for $10 \mathrm{~min}$ at $25^{\circ} \mathrm{C}$. The supernatant was discarded along with the first layer on top of the starch, which was carefully removed by scraping. The starch was washed with water $(6 \times 50 \mathrm{ml})$, collected by centrifugation and dried in lab-scale freeze-dryer (Christ, Germany). The granules were placed on specimen stubs covered with double sided adhesive tapes and sprayed with gold particles (99.9\%) in sputter coater Bal-Tec SCD050 (Balzers, Lichtenstein). The granules were observed and photographed using Scanning Electron Microscope (SEM) Zeiss EVO40 (Carl Zeiss AG, Oberkochen, Germany) with accelerating voltage of $10 \mathrm{kV}$.

\section{RESULTS AND DISCUSSION}

\section{The response surface model developed for the ethanol concentration $\left(\mathrm{Y}_{1}\right)$}

New strategy to minimize ethanol production cost is to run simultaneous saccharification and fermentation (SSF) by using the GSH enzymes. In SSF, due to the fact that yeast consume glucose, an inhibition of $\alpha$ - and glucoamylase is almost completely eliminated which ensures that all reactions proceed at a high rate. However, because of the system's complexity and interactions between the system components, several process parameters must be optimized: the substrate concentration, the dose of active components ( $\alpha$-amylase and glucoamylase) in the enzymatic mixture, and the $\mathrm{pH}$ of the fermentation slurry.

As shown in Table 3 the maximum predicted ethanol concentration reached approximately $121.8 \mathrm{~g} / \mathrm{L}$. Analysis of the variance indicated that the response surface model developed for ethanol concentration $\left(Y_{1}\right)$ was statistically significant, with the probability of the $F$ test being at a level below 0.0001. Furthermore, the probability value of the lack-of-fit test was 0.117 , indicating that the regression model is a good predictor of the experimental results. In addition, as was mentioned above, the precision of a model can be checked by the adjusted coefficient of determination Adj- $\mathrm{R}^{2}$. In the case of response $\mathrm{Y}_{1}$, the value of $\mathrm{Adj}-\mathrm{R}^{2}$ was equal to 0.841 , indicating good agreement between the experimental results and the theoretical values predicted by the model equation presented in Table 4. According to this polynomial equation, the ethanol concentration $\left(\mathrm{Y}_{1}\right)$ was linearly related to the corn flour concentration in the mash $\left(\mathrm{X}_{1}\right)$, while the quadratic term was not found to be significant, resulting in a linear increase in $\mathrm{Y}_{1}$ with $\mathrm{X}_{1}$ for all doses of GSHE $\left(\mathrm{X}_{2}\right)$ (Fig. 1). The $\mathrm{pH}$ effect was regarded as not significant $(\mathrm{p}>0.05)$, hence it was removed from the model by the ANOVA backward elimination procedure. Furthermore, it was found that the dose of GSHE $\left(\mathrm{X}_{2}\right)$ was highly significant $(\mathrm{p}<0.0001)$ in linear and quadratic terms, giving an overall curvilinear effect (Figure 1). The optimal concentrations for the two factors, as obtained from the maximum point of the model, were calculated by the Statistica software to be $34.8 \%$ and $2.08 \mathrm{ml} / \mathrm{kg}$ for the corn flour concentration $\left(\mathrm{X}_{1}\right)$ and the dose of GSHE $\left(\mathrm{X}_{2}\right)$, respectively. Similar results were presented by Wang et al. (2007), who compared the amount of ethanol and the profile of fermentable sugars during fermentation conducted according to traditional and novel technology, based on the granular starch hydrolyzing enzymes. They found that the final ethanol yield with GSH 
Table 4. Estimated coefficients of polynomial equations for investigated dependent variables using coded values. $X_{1}-$ corn flour concentration ( $\%$ wt.), $X_{2}-$ GSHE dose $(\mathrm{ml} / \mathrm{kg}$ of dry matter)

\begin{tabular}{|c|c|c|c|c|c|}
\hline Dependent variable & Term & Coefficient & Std. Err. & F-value & $\mathrm{p}$-value \\
\hline \multirow{5}{*}{$\begin{array}{l}\text { Ethanol } \\
\left(Y_{1}\right)[g / l]\end{array}$} & $\mathrm{b}_{0}$ (interc.) & 116.10 & 1.19 & & \\
\hline & $b_{1}\left(X_{1}\right)$ & 5.88 & 1.12 & 27.69 & 0.0001 \\
\hline & $b_{2}\left(X_{2}\right)$ & 4.81 & 1.12 & 18.49 & 0.0007 \\
\hline & $b_{2}^{2}\left(X_{2}^{2}\right)$ & -9.02 & 1.33 & 45.99 & $<0.0001$ \\
\hline & \multicolumn{5}{|c|}{$\begin{array}{l}Y_{1}=116.1+5.88 b_{1}+4.81 b_{2}-9.02 b_{2}{ }^{2} \\
\text { (Adj. } R^{2} 0.841 ; \text { Lack of Fit } 0.017 \text { ) }\end{array}$} \\
\hline \multirow{6}{*}{$\begin{array}{l}\text { Process yield } \\
\left(\mathrm{Y}_{2}\right)[\%]\end{array}$} & $\mathrm{b}_{0}$ (interc.) & 74.74 & 0.97 & & \\
\hline & $b_{1}\left(X_{1}\right)$ & -8.46 & 0.78 & 118.07 & $<0.0001$ \\
\hline & $\mathrm{b}_{2}\left(\mathrm{X}_{2}\right)$ & 3.20 & 0.78 & 16.91 & 0.0012 \\
\hline & $b_{1}^{2}\left(X_{1}^{2}\right)$ & 2.13 & 0.93 & 5.29 & 0.0387 \\
\hline & $\mathrm{b}_{2}^{2}\left(\mathrm{X}_{2}^{2}\right)$ & -5.91 & 0.93 & 40.36 & $<0.0001$ \\
\hline & \multicolumn{5}{|c|}{$\begin{array}{l}Y_{2}=74.74-8.46 b_{1}+3.2 b_{2}+2.13 b_{1}^{2}-5.91 b_{2}^{2} \\
\text { (Adj. } R^{2} 0.913 ; \text { Lack of Fit 0.092) }\end{array}$} \\
\hline
\end{tabular}

enzymes was comparable to the conventional enzymes, while the glucose, maltose and maltotriose concentrations had consistently lower GSH enzymes throughout fermentation. The authors concluded that GSH enzymes allow for simultaneous liquefaction, saccharification and fermentation. As mentioned above, high substrate concentration increased ethanol concentration in the SSF, but our results also indicated that ethanol concentration was not highly correlated with the second investigated variable — the overall process yield $\left(\mathrm{Y}_{2}\right)$, as shown by the value of Pearson correlation coefficient $r$, equal to 0.22 , with $\mathrm{p}=0.35$. For example, when fermentation was conducted under optimal conditions to reach maximum ethanol concentration, the predicted overall yield was only $69.4 \%$. If we assume that the yields attained in traditional technology, based on fermentation of gelatinized starch, do not usually exceed 90 to $95 \%$ of the theoretical value, our results are definitely lower. This clearly indicates that besides ethanol concentration, the

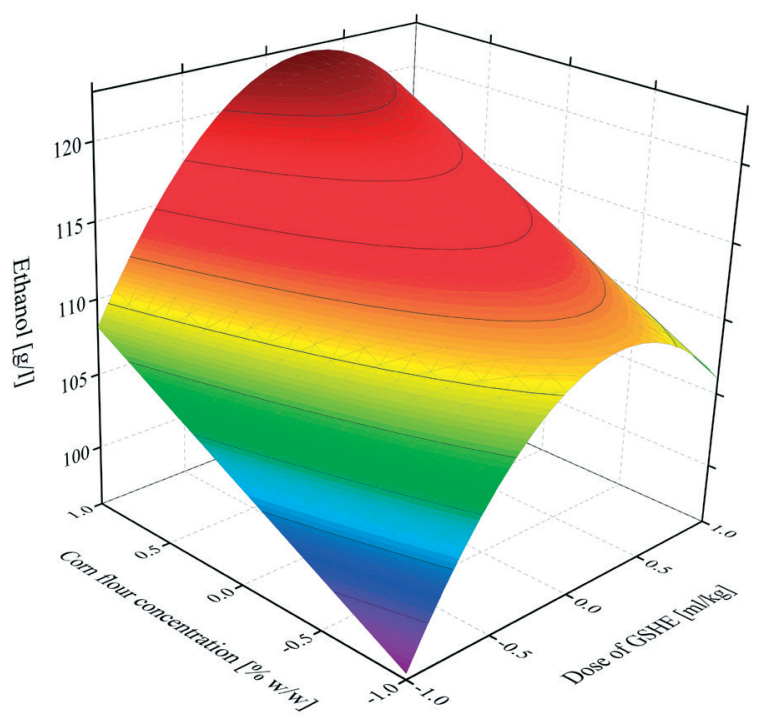

Figure 1. Three dimensional plot showing the effect of corn flour concentration and dose of GSHE on the ethanol concentration after fermentation $\left(\mathrm{Y}_{1}\right)$.

The $\mathrm{pH}$ was fixed at zero coded level. GSHE - granular starch hydrolyzing enzymes overall process yield — expressed as the theoretical yield of ethanol/ starch - is also an important factor affecting the ethanol production cost from starchy feedstock. Consequently, the overall process yield $\left(\mathrm{Y}_{2}\right)$ was taken into consideration in the optimization of simultaneous saccharification and fermentation of corn flour mashes.

\section{The response surface model developed for the overall process yield $\left(\mathrm{Y}_{2}\right)$}

According to Lee (2007) the principal advantage of ethanol production through the fermentation of starch, especially gelatinized starch, is in its technological simplicity and efficiency. As was mentioned earlier, the process yield in traditional technology falls into the range of $90-95 \%$, thereby providing high economic profitability. From the data presented in Table 3, it can be seen that the yield was within the limits of $51.2-86.9 \%$, which corresponds to the residual starch range being between 3.4 and $11.5 \mathrm{~g} / 1$ (not shown). Not surprisingly, these two dependent variables were highly correlated. The calculated Pearson correlation coefficient $r$ was equal to $-0.95(\mathrm{p}<0.0001)$. Experimental results of the CCD design were fitted into the second-order polynomial (Table 4). The fit of the model was checked by the adjusted coefficient of determination Adj- $\mathrm{R}^{2}$, which was calculated to be 0.913 , indicating that $91.3 \%$ of the variability in the response could be explained by the model. Statistical significance of the second-order model equation was evaluated by the F-test analysis of variance, which revealed that this regression is statistically significant, showing $\mathrm{p}<0.0001$ at $95 \%$ of confidence level. In addition, the $\mathrm{p}$ value of lack of fit test was 0.092 which exceeds the critical value of 0.05 . This means that the model adequately fits the response data.

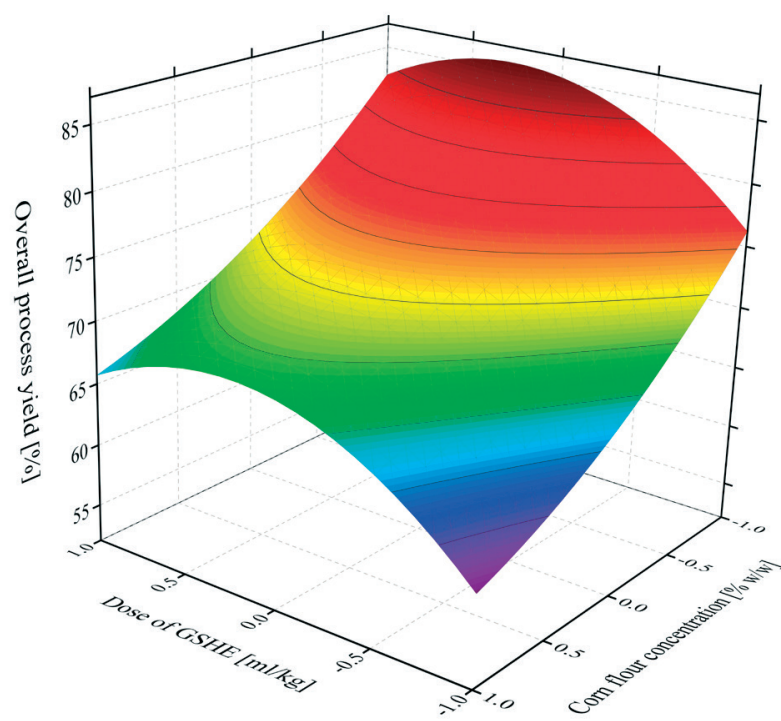

Figure 2. Three dimensional plot showing the effect of corn flour concentration and dose of GSHE on the overall process yield $\left(\mathrm{Y}_{2}\right)$.

The $\mathrm{pH}$ was fixed at zero coded level. GSHE - granular starch hydrolyzing enzymes 
Regression analysis of $\mathrm{Y}_{2}$ showed that when the independent variables $\mathrm{X}_{1}$ and $\mathrm{X}_{2}$ were investigated, they were significant at the probability levels of $95 \%$, and proved to be the two most influential factors on the process yield. The $\mathrm{pH}\left(\mathrm{X}_{3}\right)$ was found to be insignificant at the probability level of $95 \%$ and consequently was removed from the model by the ANOVA backward elimination procedure. Moreover, a comparison of the regression coefficient (Table 4) indicates that the value of $\mathrm{Y}_{2}$ was much more influenced by the value of $\mathrm{X}_{1}$ than by the value of $\mathrm{X}_{2}$. It can further be seen that the main effects for the independent variables $\mathrm{X}_{1}$ have a negative sign, which means that the investigated value progressively decreased when the corn flour concentration in the mash increased (Fig. 2). The data show that this dependence is different to that obtained during the analysis of variable $\mathrm{Y}_{1}$ (ethanol concentration). Additionally, the secondorder effects for independent variables $\mathrm{X}_{2}$ also have a negative sign, meaning that the investigated value increased to reach a maximum, and then sharply decreased (Fig. 2). The following conclusions can be drawn from these relationships: to achieve the maximum ethanol concentration $\mathrm{Y}_{1}$ a high hydrolysis rate is crucial to provide a sufficient level of reducing sugars. At the same time, to obtain the highest possible process yield $Y_{2}$, the utilization of mashes with a lower substrate concentration is recommended. Thus, starch losses may have occurred to a relatively reduced extent. Furthermore, the optimal concentrations for the two factors, as obtained from the maximum point of the model, were calculated by the Statistica software to be $25.0 \%$ and $2.18 \mathrm{ml} / \mathrm{kg}$ for the corn flour concentration in the mash $\left(\mathrm{X}_{1}\right)$ and for the dose of GSHE $\left(\mathrm{X}_{2}\right)$, respectively. It is worth noting that the results obtained in our investigation are in excellent agreement with an earlier study of Suresh et al. (1999). They also reported that the maximum ethanol yield was obtained in a $250 \mathrm{~g} / 1$ starch medium. Similar observations concerning relationship between starch concentration and ethanol yield have been made by Abouzied \& Reddy (1987). It must be taken into account that contrary to the previous optimization step concerning ethanol concentrations, the indicated value of the mash concentration $\left(\mathrm{X}_{1}\right)$ is considerably lower. Therefore, in order to find the best compromise between ethanol concentration and the process yield, a multicriteria decision making approach has to be used.

\section{Process optimization}

A typical problem in a simultaneous saccharification and fermentation processes is to find a set of conditions for the input variables that ensure the highest concentration of ethanol and overall process yield. The procedures used to solve this problem involve several steps: responses on the dependent variable $Y_{i}$ are predicted by fitting the observed response, using an equation based on the levels of the independent variables, and by finding the levels of independent variables which produce the most desirable predicted response. This relationship between predicted response $\mathrm{Y}_{\mathrm{i}}$ on one or more dependent variables and the desirability of the response is called the desirability function (Derringer \& Suich, 1980). Presented results clearly indicate that the concentration of ethanol as well as the overall process yield can be affected mainly by altering the investigated independent variables $\mathrm{X}_{1}$ an $\mathrm{X}_{2}$. For that reason, the following conditions were imposed: the corn flour concentration in the mash, the dose of GSHE and the $\mathrm{pH}$ had coded values from -1.0 to +1.0 . At the same time, the ethanol concentration $Y_{1}$ and the overall process yield $Y_{2}$ were maintained at the highest possible level, respectively. Before optimization, the response variables $Y_{i}$ were converted into the desirability function $\mathrm{D}$ that varies from 0 to 1 where, if the response is at its goal or target, then $\mathrm{D}=1$, and if the response is outside an acceptable region, $\mathrm{D}=0$. Applying desirability function methodology, the best combination of variables $\mathrm{X}_{1}, \mathrm{X}_{2}$ and $\mathrm{X}_{3}$ for maximizing both $\mathrm{Y}_{1}$ and $\mathrm{Y}_{2}$ responses simultaneously has been found to be $\mathrm{X}_{1}=25 \%, \mathrm{X}_{2}=2.05 \mathrm{ml} / \mathrm{kg}$ and $\mathrm{X}_{3}=5.0$, respectively.

\section{Validation of the model and optimal conditions}

In order to verify the adequacy of the model and the optimal conditions developed, four confirmation run experiments were performed (Table 5). The test conditions for the first three confirmation run experiments were taken from the cutting conditions performed previously, whilst the last confirmation run experiment was performed within the range of levels defined at the optimization stage. The predicted values and the actual experimental values were compared, and it can be observed that most values determined experimentally were similar to those determined by the developed models, which definitely proved the validity of the experiments.

\section{Kinetics study}

In order to increase starch conversion efficiency, several kinetics models have been developed. Important contributions in this field were made by Polaković \& Bryjak (2004), as well as by Kroumov et al. (2006). The essential feature of the model developed by Polakovic \& Bryjak (2004) was that starch was structured into susceptible and resistant fractions that differed in the rate constants of hydrolysis. This assumption gave a good approximation of the substrate and product concentration profile during hydrolysis. A mathematical description of a simultaneous saccharification and fermentation of starch by recombinant strain of Saccharomyces cerevisiae YPB-G

Table 5. Validation results. Act. - actual, Pred. - predicted, $X_{1}$ - corn flour concentration (\% wt.), $X_{2}-$ GSHE dose (ml/kg of dry matter), $\mathrm{X}_{3}-$ mash $\mathrm{pH}$

\begin{tabular}{|c|c|c|c|c|c|c|c|c|c|c|}
\hline \multirow{3}{*}{$\mathrm{X}_{1}$} & \multirow{3}{*}{$\mathrm{X}_{2}$} & \multirow{3}{*}{$X_{3}$} & \multicolumn{4}{|c|}{$Y_{1}$ - ethanol concentration } & \multicolumn{4}{|c|}{$\mathrm{Y}_{2}$ - overall process yield } \\
\hline & & & \multirow{2}{*}{ Act. } & \multirow{2}{*}{ Pred. } & \multicolumn{2}{|c|}{ Conf. Interval } & \multirow{2}{*}{ Act. } & \multirow{2}{*}{ Pred. } & \multicolumn{2}{|c|}{ Conf. Interval } \\
\hline & & & & & $-95 \%$ & $95 \%$ & & & $-95 \%$ & $95 \%$ \\
\hline 26.04 & 0.87 & 4.0 & 101.1 & 99.9 & 96.5 & 103.4 & 75.7 & 75.2 & 72.8 & 77.6 \\
\hline 32.92 & 2.79 & 5.0 & 115.0 & 117.5 & 114.5 & 120.5 & 67.9 & 69.2 & 67.0 & 71.4 \\
\hline 33.66 & 1.95 & 3.6 & 115.2 & 120.7 & 117.6 & 123.8 & 66.5 & 69.9 & 67.7 & 72.1 \\
\hline 25.00 & 2.05 & 5.0 & 110.4 & 110.8 & 107.3 & 114.3 & 85.7 & 85.7 & 83.1 & 88.3 \\
\hline
\end{tabular}



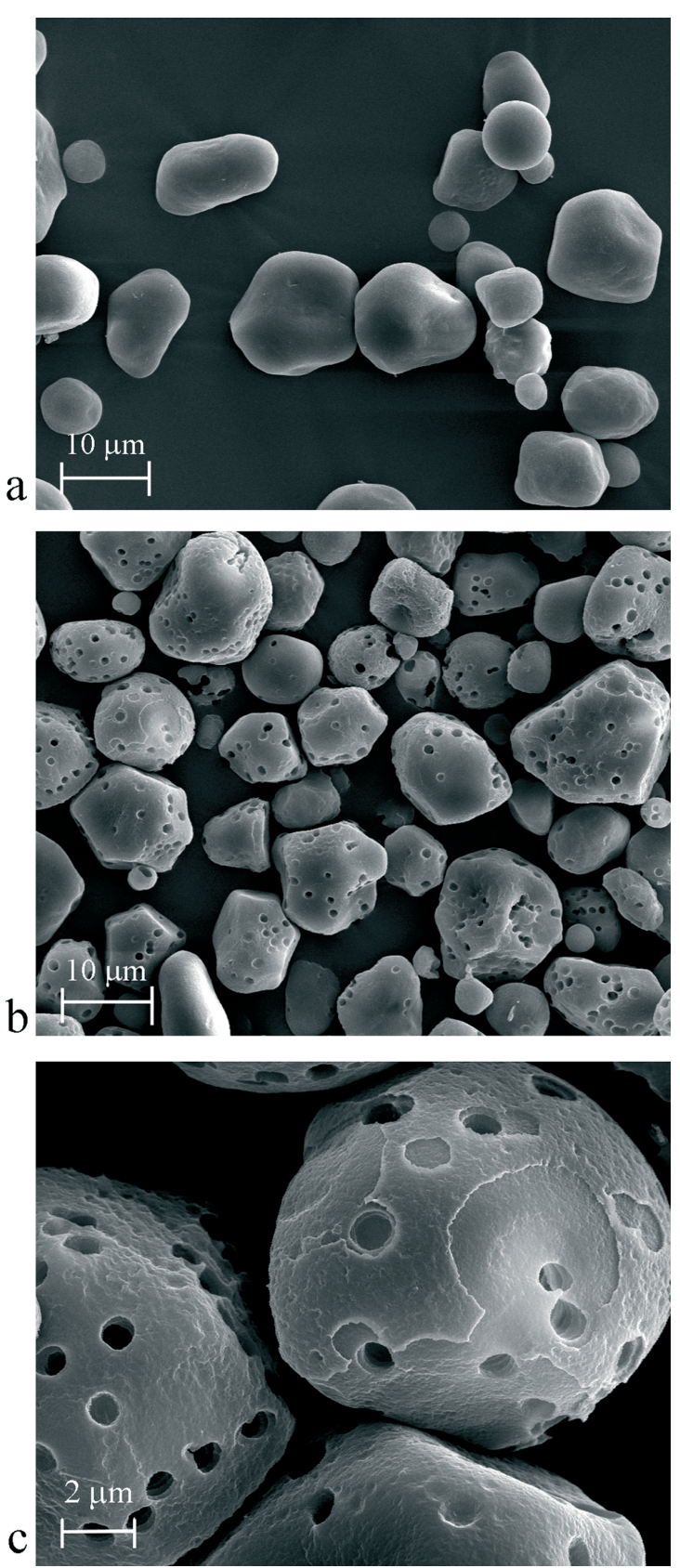

Figure 3. Scanning electron micrograph showing untreated raw corn starch granules (a) and ruptured raw corn starch granules after SSF with granular starch hydrolyzing enzymes (b, c). SSF - simultaneous saccharification and fermentation

was developed and described in detail by Kroumov et al. (2006). In this work, the concept of starch being structured into susceptible and resistant fractions was also applied. Furthermore, the authors assumed that the specific growth rate of the recombinant strain was influenced by glucose, and by initial and total starch concentrations. The specific ethanol production rate was described as a function of glucose, initial starch and ethanol concentrations. According to the data presented by Kroumov et al. (2006) the proposed model showed excellent flexibility for different operational conditions of the SSF process, and could be used successfully to describe microbial physiology of the genetically modified yeast Saccharomyces cerevisiae, secreting enzymes for starch degradation. In the present work, however, an attempt has been made to apply this knowledge to the modeling of saccharifica- tion and fermentation of mashes containing native corn starch, using enzymes of hydrolyzing granular starch and the distiller's yeast Ethanol Red (Saccharomyces cerevisiae). It is well known that most starches are triphasic with alternating concentric growth rings or lamella of amorphous and semi-crystalline character, as well as lipid amylase inclusion complexes (Oostergetel \& van Bruggen, 1993; Morgan et al., 1995). Moreover, scanning electron microscopy has shown that there are randomly distributed depressions on the surface of wet starch granules. These depressions are suspected architecturally of being enzyme-susceptible regions (Robertson et al., 2006). This suggests that the biphasic kinetic model developed by Polaković \& Bryjak (2004) could also be useful for describing the digestion of raw starch by $\alpha$ - and glucoamylase. However, according to Robertson et al. (2006), an uncritical extrapolation of the laboratory observations to technical processes has to consider that starch preparation for the enzymatic studies may, for instance, include a solvent extraction in order to eliminate lipid effects. Sample preparation may introduce artefacts, through dehydratation and/or physical abrasion. Thus, contrary to the data presented by Polaković \& Bryjak (2004) as well as that of Kroumov et al. (2006), granular starch in the corn flour was considered to be a homogenous material containing only one fraction. In our opinion, based on limited available information concerning the proportion of potentially susceptible and resistant fractions in raw starch, it is difficult or impossible to formulate correct estimate of the rate constants. Consequently, if it is assumed that only a single substrate containing starch with some percentage of glucose is added, then the model equations are written as follows:

Enzymatic rate of starch degradation:

$$
R_{S t}=\frac{k_{S t} \cdot \operatorname{Enz} \cdot \operatorname{St}(t)}{K_{m} \cdot\left(1+\frac{G l u(t)}{K_{G l u}}\right)+\frac{S t(t)^{2}}{K_{S t}}+S t(t)}
$$

Mass balance of starch degradation:

$$
\frac{d S t(t)}{d t}=-R_{S t}
$$

Balance of glucose produced during starch degradation:

$$
\frac{d G l u(t)}{d t}=1.111 \cdot\left(R_{S t}\right)
$$

Biomass balance:

$$
\frac{d X(t)}{d t}=\mu \cdot X(t)
$$

and the specific growth rate model:

$$
\mu=\frac{\mu_{\max } \cdot G l u(t) \cdot\left(\frac{S t(t)}{S t_{0}}\right)}{K_{s}+G l u(t)}
$$

Product balance:

$$
\frac{d E t(t)}{d t}=q_{p} \cdot X(t)
$$

and the production rate model:

$$
q_{p}=\frac{q_{p_{\max }} \cdot G l u(t) \cdot E t(t) \cdot\left(1-\frac{E t(t)}{E t_{\max }}\right)}{\left(K_{s 1}+G l u(t)\right) \cdot\left(K_{p s 1}+E t(t)+\frac{E t(t)^{2}}{K_{p i}}\right)}
$$


Glucose balance:

$$
\frac{d G l u(t)}{d t}=R_{G l u}(\text { formation })-R_{G l u}(\text { utilization })
$$

where:

$$
\begin{gathered}
R_{\text {Glu }}(\text { formation })=1.111 \cdot\left(R_{S t}\right) \\
R_{G l u}(\text { utilization })=\frac{1}{Y_{X / S}} \cdot \frac{d X(t)}{d t}+\frac{1}{Y_{P / S}} \cdot \frac{d E t(t)}{d t}
\end{gathered}
$$

The reaction rate for hydrolysis of the starch is a Michaelis-Menten kinetic model, which considers the substrate inhibition of starch $\mathrm{K}_{\mathrm{St}}$ as well as the competitive product inhibition of glucose $\mathrm{K}_{\text {Glu. }}$. It should be noted that the model considers only one enzyme activity involved in starch degradation to glucose by the synergetic action of $\alpha$ - and glucoamylases. In the present study, similar to the works of Kroumov et al. (2006) and Davis (2008), we have assumed that this two-enzyme action can be simplified and represented as a sum of individual enzyme activities. As shown in Table 6, estimated values of the kinetic parameters concerning starch hydrolysis indicate that the enzyme complex investigated is greatly inhibited by glucose $\left(\mathrm{K}_{\mathrm{Glu}}=0.0857\right)$, whereas the substrate inhibition of starch should be regarded as an insignificant factor $\left(\mathrm{K}_{\mathrm{St}}=999.98\right)$. Similar conclusions were drawn by Polaković \& Bryjak (2004) as well as by Kroumov et al. (2006). However, a striking discrepancy between their results was observed concerning $\mathrm{K}_{\mathrm{St}}$ and $\mathrm{K}_{\mathrm{Glu}}$ and the present data. Respectively, the inhibition constant $K_{\mathrm{St}}$ value exceeded $60 \mathrm{~kg} / \mathrm{m}^{3}$, whereas the $K_{\text {Glu }}$ value was $1.1 \mathrm{~kg} / \mathrm{m}^{3}$. It might therefore contribute to the use of the raw starch as a substrate and a different enzyme system. In addition, the estimated value of the rate constant $\mathrm{k}_{\mathrm{St}}$ was almost 100 times lower than the rate constant obtained by Kroumov et al. (2006). It is probable that the rate of soluble starch digestion was much faster, because $\alpha-1.4$-bonds for $\alpha$-amylase and $\alpha-1.4$ bonds at nonreducing ends for glucoamylases were readily susceptible to an enzyme attack, whereas in the case of the digestion of native starch granules, polysaccharide backbones were concentrated in the solid-phase portion

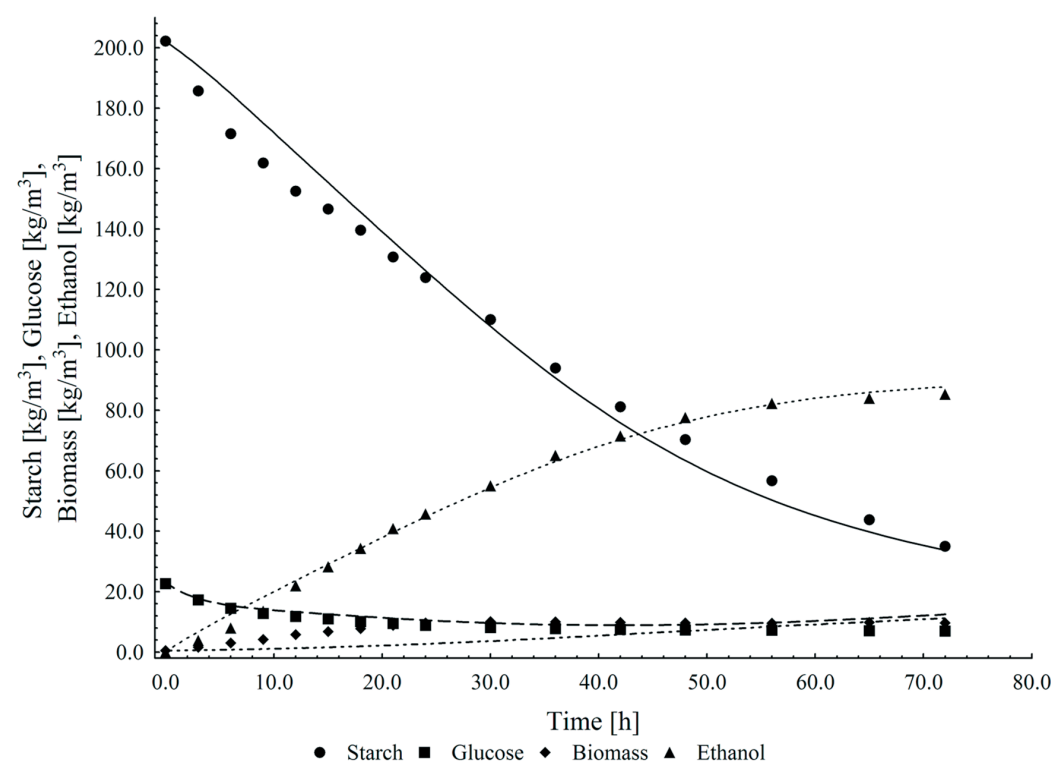

Figure 4. Kinetics of simultaneous saccharification and fermentation of corn flour

\begin{tabular}{|c|c|c|c|}
\hline No. & Parameters & Value & Unit \\
\hline \multicolumn{4}{|c|}{ Initial } \\
\hline 1 & $\mathrm{St}_{0}$ & 202.34 & $\mathrm{~kg} / \mathrm{m}^{3}$ \\
\hline 2 & $\mathrm{Glu}_{0}$ & 23.03 & $\mathrm{~kg} / \mathrm{m}^{3}$ \\
\hline 3 & $x_{0}$ & 0.5 & $\mathrm{~kg} / \mathrm{m}^{3}$ \\
\hline 4 & $\mathrm{Et}_{0}$ & 0.0 & $\mathrm{~kg} / \mathrm{m}^{3}$ \\
\hline 5 & Enz & 262612.5 & $\mathrm{U} / \mathrm{m}^{3}$ \\
\hline \multicolumn{4}{|c|}{ Estimated } \\
\hline 1 & $\mathrm{~K}_{\mathrm{m}}$ & 26.998 & $\mathrm{~kg} / \mathrm{m}^{3}$ \\
\hline 2 & $\mathrm{k}_{\mathrm{st}}$ & 0.000333 & $\mathrm{~kg} / \mathrm{U} \cdot \mathrm{h}$ \\
\hline 3 & $\mathrm{~K}_{\mathrm{st}}$ & 999.98 & $\mathrm{~kg} / \mathrm{m}^{3}$ \\
\hline 4 & $\mathrm{~K}_{\mathrm{Glu}}$ & 0.0857 & $\mathrm{~kg} / \mathrm{m}^{3}$ \\
\hline 5 & $\mu_{\max }$ & 0.6057 & $\mathrm{~h}^{-1}$ \\
\hline 6 & Ks & 7.0237 & $\mathrm{~kg} / \mathrm{m}^{3}$ \\
\hline 7 & $q_{p \max }$ & 4.9951 & $\mathrm{~h}^{-1}$ \\
\hline 8 & $E t_{\max }$ & 90.007 & $\mathrm{~kg} / \mathrm{m}^{3}$ \\
\hline 9 & $\mathrm{~K}_{\mathrm{s} 1}$ & 0.00633 & $\mathrm{~kg} / \mathrm{m}^{3}$ \\
\hline 10 & $\mathrm{~K}_{\mathrm{ps} 1}$ & 0.00046 & $\mathrm{~kg} / \mathrm{m}^{3}$ \\
\hline 11 & $\mathrm{~K}_{\mathrm{pi}}$ & 14.687 & $\mathrm{~kg} / \mathrm{m}^{3}$ \\
\hline 12 & $Y_{p / s}$ & 0.4759 & $\mathrm{~kg} / \mathrm{kg}$ \\
\hline 13 & $Y_{x / s}$ & 0.8133 & $\mathrm{~kg} / \mathrm{kg}$ \\
\hline
\end{tabular}
mash conducted in a $5 \mathrm{~L}$ volume bioreactor
Table 6. The SSF initial and estimated kinetic parameters

of the reaction mixture. Several different suggestions have been put forward concerning the routes of raw starch granules digestion. These include: local or distributed digestion at the surface pores, centripetal digestion along the starch polymer chains, digestion at the cracks, or diffusion through the starch structure to susceptible sites (Robertson et al., 2006). However, the most probable explanation has been deduced by Matsubara et al. (2004), from the microscopic observation of corn starch granules hydrolyzed with a mixture of $\alpha$ - and glucoamylase. They claim that glucoamylase initially acted on the starch granule surface, forming small holes, whereas $\alpha$-amylase was adsorbed around the hole and released oligosaccharides, which were further decomposed to glucose by the action of glucoamylase. Furthermore, when the above-mentioned enzymes were used together, they created more holes per unit area, and the size of the holes was expanded further. Thus, when the substrate was digested, additional sites for the reaction were exposed. Scanning electron microscopy of the starch granules isolated from fermented mash supports the efficient action of enzyme preparation used in this study towards raw corn starch. Figure 3 a shows that the surface of untreated starch granules was smooth, whereas Figs $3 b$ and $3 c$ shows that the pores of the hydrolyzed starch were randomly distributed due to the breakdown of granules by the 
GSH enzyme. It is worth pointing out that, according to Robertson et al. (2006) the representation of an initial substrate concentration is ambiguous, and probably has some effect on the estimate of the rate constant $\mathrm{k}_{\mathrm{St}}$. On the other hand, when the STARGEN 001 was used during the SFF of food waste containing starch, the inhibition coefficients $K_{S t}$ and $K_{G l u}$ also differed from those estimated in the present work, despite the fact that the estimated value of $\mathrm{K}_{\mathrm{m}}$ equal to $26.998 \mathrm{~kg} / \mathrm{m}^{3}$ agreed well with the value of $27 \mathrm{~kg} / \mathrm{m}^{3}$ found by Davis (2008). According to Davis (2008) the values of $\mathrm{K}_{\mathrm{St}}$ and $\mathrm{K}_{\mathrm{Glu}}$ were equal to 0.076 and $0.5 \mathrm{~kg} / \mathrm{m}^{3}$, respectively. Thus, under these conditions, the rate of starch hydrolysis was highly dependent on the substrate as well as the product concentration. This definitely confirms that both, molecular and physical structure of the solid substrate, and molecular configuration of the enzyme used, may contribute to the hydrolysis as well as to the fermentation efficiency. Thus, a direct comparison with other studies becomes difficult, especially since most available correlations are made for gelatinized starch. However, our results for ethanol yield $\mathrm{Y}_{\mathrm{p} / \mathrm{s}}$, agree well with the results obtained by Kroumov et al. (2006) and Davis (2008) as well as Montesinos \& Navarro (2000), who studied the SSF process of alcohol production from gelatinized wheat flour using amyloglucosidase and the yeast Saccharomyces cerevisiae.

Finally, it could be said that, in spite of complexity, the model predicts experimental data reasonably well, as can be seen in Fig. 4. The discrepancies between simulation results and experimental data could be due to several reasons, which differ from those discussed earlier. There is some uncertainty in the method used to determine the concentration of yeast cells employed in these experiments. Because of the high concentration of corn flour particles, the yeast cell populations were determined by a direct microscopic count in a counting chamber after staining with methylene blue. The yeast cell number was recalculated to express the biomass concentration as kilogram per cube meter, according to the assumption that weight of an individual yeast cell is equal to $7.99 \times 10^{-11} \mathrm{~g}$, with a standard deviation 3.188 $\times 10^{-11} \mathrm{~g}$ (Haddad \& Lindergren, 1953). Consequently, considering this standard deviation, if this approach is used for biomass determination, it can lead to inaccurate results. Unfortunately, besides the data presented by Haddad \& Lindegren (1953), no relevant experimental framework exits for the determination of the weight of an individual yeast cell.

\section{CONCLUSIONS}

According to the optimization results, the maximum ethanol concentration of $110.36 \mathrm{~g} / \mathrm{l}$ was obtained using mash concentration of $25 \%$, which resulted in the predicted ethanol yield of $85.71 \%$. The optimum conditions for the above yield were found for enzyme dose of 2.05 $\mathrm{ml} / \mathrm{kg}$ and $\mathrm{pH}$ of 5.0. Nevertheless, it is possible to increase the concentration of starch in the stream feeding the fermentor to above $35 \%$. A reasonable approach to the increase in the productivity of alcoholic fermentation of the concentrated mashes is the removal of the product, for instance by applying pervaporation or membrane distillation. Coupling of the SSF with the above mentioned separation systems reduces natural inhibitions of cell growth caused by high concentrations of ethyl alcohol, whereas the SSF process permits reduction of the enzyme inhibition by glucose during starch hydrolysis. In summary, the results reported in this work show that the
SSF process applied to native starch, using novel GSH enzymes, stands as an excellent alternative for traditional technology in the production of fuel ethanol. This may lead to more sustainable processing, characterized by less energy consumption, larger volumetric productivity, as well as a better utilization of substrates.

\section{Acknowledgements}

This work was supported by the Polish Ministry of Science and Higher Education under Iuventus Plus Grant No IP2010 002570 and Grant No 0619/P01/2007/02.

\section{REFERENCES}

Abouzied MM, Reddy CA (1987) Fermentation of starch to ethanol by a complementary mixture of an amylolytic yeast and Saccharomyces cerevisiae. Biotechnol Lett 9: 59-62.

Davis RA (2008) Parameter estimation for simultaneous saccharification and fermentation of food waste into ethanol using matlab simulink. Appl Biochem Biotechnol 147: 11-27.

Derringer G, Suich R (1980) Simultaneous optimization of several response variables. Journal of Quality Technology 12: 214-219.

Haddad SA, Lindegren CC (1953) A Method for determining the weight of an individual yeast cell. Appl Microbiol 3: 153-156.

Holm J, Björck I, Drews A (1986) A rapid method for the analysis of starch. Starch-Stärke 7: 224-226.

Kobayashi F, Sawada T, Nakamura Y, Ohnaga M, Godliving M, Ushiyama $T$ (1998) Saccharifcation and alcohol fermentation in starch solution of steam-exploded potato. Appl Biochem Biotechnol 69: 177189.

Kroumov AD, Módenes AN, de Araujo Tait MC (2006) Development of new unstructured model for simultaneous saccharification and fermentation of starch to ethanol by recombinant strain. Biochem Eng J 28: 243-255.

Lee S (2007) Ethanol from corn. In Handbook of Alternative Fuel Technologies. Lee S, Speight JG, Loyalka SK, eds, pp 232-343. CRC Press, Boca Raton.

Lim LH, Macdonald DG, Hill GA (2003) Hydrolysis of starch particles using immobilized barley $\alpha$-amylase. Biochem Eng J 13: 53-62.

Matsubara T, Ammar YB, Ito K, Iizuka M, Minamiura N, Anindyawati T, Yamamoto $S$ (2004) Degradation of raw starch granules by $\alpha$-amylase purified from culture of Aspergillus awamori KT-11. Biochem Mol Biol 37: 422-428.

Montesinos T, Navarro JM (2000) Production of alcohol from raw wheat flour by Amyloglucosidase and Sacharomyces cerevisiae. Enzyme Microb Technol 27: 362-370.

Montgomery DC (2001) Design and analysis of experiments. 5th edn. John Wiley \& Sons Inc; New Jersey.

Montgomery DC, Runger GC (2003) Applied Statistics and Probability for Engineers. 3rd edn. John Wiley \& Sons Inc, New Jersey.

Morgan KR, Furneaux RH, Larsen NG (1995) Solid-state NMR studies on the structure of starch granules. Carbohydr Res 276: 387-399.

Nichols NN, Dien BS, Bothast RJ, Cotta MA (2006) The Corn Ethanol Industry. In Alcoholic Fuels. Minteer S, ed, pp 59-79. CRC Press, Boca Raton.

Öhgren K, Bura R, Lesnicki G, Saddler J, Zacchi G (2007) A comparison between simultaneous saccharification and fermentation and separate hydrolysis and fermentation using steam-pretreated corn stover. Process Biochem 42: 834-839.

Öhgren K, Rudolf A, Galbe M, Zacchi G (2006) Fuel ethanol production from steam-pretreated corn stover using SSF at higher dry matter content. Biomass Bioenergy 30: 863-869.

Oostergetel GT, van Bruggen EFJ (1993) The crystalline domains in potato starch granules are arranged in a helical fashion. Carbohydr Polym 21: 7-12.

Philippidis GP, Smith TK (1995) Limiting factors in the simultaneous saccharification and fermentation process for conversion of cellulosic biomass to fuel ethanol. Appl Biochem Biotechnol 51/52: 117-124.

Polakovic M, Bryjak J (2004) Modelling of potato starch saccharification by an Aspergillus niger glucoamylase. Biochem Eng 18: 57-63.

Power RF (2003) Enzymatic conversion of starch to fermentable sugars. In. The Alcohol Textbook, fourth ed. Jacques KA, Lyons TP, Kelsall DR, eds, pp 23-32. Nottingham University Press, Nottingham.

Robertson GH, Wong DWS, Lee CC, Wagschal K, Smith MR, Orts WJ (2006) Native or Raw Starch Digestion: A Key Step in Energy Efficient Biorefining of Grain. I Agric Food Chem 54: 353-365.

Senn T, Pieper HJ (2001) Part 1. Classical Methods. In The Biotechnology of Ethanol: Classical and Future Applications. Roehr M, ed, pp 1-87. WILEY-VCH Verlag GmbH, Weinheim. 
Suresh K, Kiran Sree N, Venkateswar Rao L (1999) Production of ethanol by raw starch hydrolysis and fermentation of damaged grains of wheat and sorghum. Bioprocess Eng 21: 165-168.

Verma G, Nigam P, Singh D, Chaudhary K (2000) Bioconversion of starch to ethanol in a single-step process by coculture of amylolytic yeasts and Saccharomyces cerevisiae 21. Bioresour Technol 72: 261-266.

Wang P, Singh V, Hue X, Johnston DB, Rausch KD, Tumbleson ME (2007) Comparison of raw starch hydrolyzing enzyme with conventional liquefaction and saccharification enzymes in dry-grind corn processing. Cereal Chem 84: 10-14.
Ward C, Nolan AM, O`Hanlon K, McAree T, Barron N, McHale L, McHale AP (1995) Production of ethanol at $45^{\circ} \mathrm{C}$ on starch containing media by a mixed culture of thermotolerant, ethanol producing yeast Kluveromyces marxianus CBS 814.70 and a thermophilic filamentous fungus Taloromyces emersonii. Appl Microbiol Biotechnol 43: $408-411$.

Wyman CE (2003) Applications of corn stover and fiber. In Corn Chemistry and Technology, second ed. White PJ, Johnson LA, eds, pp 723-750. American Association of Cereal Chemists, St. Paul MN. 